INTERNATIONAL DESIGN CONFERENCE - DESIGN 2018

https://doi.org/10.21278/idc.2018.0116

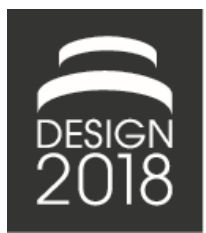

\title{
DESIGNERS' IDENTITY: SKILLS' SELF-PERCEPTION AND EXPECTATION IN DESIGN STUDENTS
}

\author{
K. Kunrath, P. Cash and J. Li-Ying
}

\begin{abstract}
Designers' Professional Identity (DPI) combines social- and self-perceptive awareness through which one is able to identify as a designer. However, self-perception can be different from the expectations associated with an ideal designer, especially during education. Thus, this paper reports a survey where self-perceived design skills and expectation are compared at different points in a design education. Findings indicate that changes in mindset modify the alignment between self-perception and expectations, which provides implications for education and for a broader understanding of DPI.
\end{abstract}

Keywords: professional identity, competence expectation, design education, design learning, human behaviour

\section{Introduction}

The process through which a designer comes to develop a distinct professional identity plays an important role in professional development. This is particularly significant for design students, as it is key to building self-confidence and self-realization as a qualified professional. This sense of belonging to a profession can be seen as a social- and self-perceptive awareness of professional values and skills, integral to the professional mindset. Ultimately alignment between self-perception and expectations of the profession is key to self-realization and work performance in a specific role.

The professional consciousness is a core element of personal identity and thus plays an important role in one's confidence and professional development (Skorikov and Vondracek, 2011). However, inconsistencies between self-perception and expectation can disrupt confidence building and sense of belongingness in the professional context, negatively impacting the process of professional identity formation. The main components associated with the formation of a Designers' Professional Identity (DPI) are the level of awareness of personal skills and their alignment with internal and external expectations (Haslam and Ellemers, 2011; Kunrath et al., 2016).

The external expectations that contribute to this professional understanding are the basis for stereotyping the designer. Here, key characteristics have been widely discussed as designerly ways of thinking and as trained competences and abilities (Cross, 1982; Adams et al., 2011). However, in each specific context the expected characteristics of a 'good designer' may vary e.g. educational, society understanding, or work environment. During education, the goal of skills acquisition is directed by academic rubrics and evolves towards an expected set of characteristics previously established by the university's curriculum and approach to design. However, the way in which students - at different levels of education - perceive themselves in this context is less specifically managed. As such, discrepancies between the stereotype of an 'ideal designer' and the students' self-perceptions can impact the development of Designers' Professional Identity (DPI). Similarly, understanding of professional role and the feeling of belonging to a professional group can be undermined by divergence between self- 
perception and external expectation. As such, there is a key research need to understand how the interaction between these elements (required skills and expectation) changes over time in the context of design education.

To address this need this paper seeks to take the first steps in answering the RQs: 1) How does students' expectation, of the ideal skills composition for a designer, evolve over the course of education? 2) What are the differences between the students' self-perception and expectations? To answer these RQ's this paper presents data from a psychometric survey combined with a skills rating exercise, carried out with first year Bachelors and final year Masters Design students. Results are discussed based on the first descriptive statistical analysis and implications are derived for design theory and practice.

\section{Literature review}

The study of professional identity has deep roots in psychology, where the aspects of self and identity have been widely discussed as the point around which personal development and occupational identity interact (e.g. Schwartz et al., 2011). The way in which somebody perceives themselves as a professional is a reflection of self-awareness and is usually based on an expectation of an ideal model, seen as a goal to be achieved. This inspirational stereotype guides the development of a self-understanding and the sense of being part of a professional group (Haslam and Ellemers, 2011). The process of professional identification formally starts during professional education and, by running life-long, impacts the development of confidence as a professional as well as overall performance at work (Dannels, 2000; Schwartz et al., 2011).

In this setting the Designers' Professional Identity is a topic that embraces not only psychological issues during education but also elements of management and human resources in the job market. Here, professional identity determines professional satisfaction and improvements in competence and performance within the work environment (Ashcraft, 2013). Particularly for designers, the consolidation of a professional identity contributes to a smoother transition from student to professional status by promoting a professional development path based on awareness of what it means to be a designer in practice. Hence, professional understanding enables students to better adapt to the challenges in a field (Evetts, 2003; Tracey and Hutchinson, 2013).

Theoretical models from adult education research suggest that expectation-value approaches (i.e. Wigfield and Eccles, 2000; that postulate a positive relation between intrinsic motivation and competence beliefs) can promote further learning, motivation, and self-efficacy; and together with emotions associated with prior experience, are considered to be central to adult learning (Freiberger et al., 2012; Gorges and Kandler, 2012). Thus, understanding and aligning students expectation and professional understanding is an important part of professional development, and describes a gap between students' expectations in competencies, based on university requirements, and the characteristics actually demanded from real-world employers (Wells et al., 2009).

To address this need educators often use simulations and projects to build awareness of real world challenges. As suggested by Luehmann (2007), "this approach to learning gives participants opportunities to experience success in meaningful ways and in scaffolded situations, and thus encourages ongoing engagement" (p.289). However, there are challenges in incorporating additional experiences from practice in the education (Luehmann, 2007), and also in promoting identity development in ways that are rich in self-reflective processes and point to an achievable professional expectation model. The alignment between expectation and self-perception is illustrated in Figure 1, which forms the research framework for this work. Here, self-perception moves towards alignment with professional expectation, as knowledge and expertise are acquired over an education. In design practice, this would imply that the shared professional beliefs (such as ethics and social impact approaches), role understanding and assumptions - intrinsic to the professional title - would predetermine actions and practices expected from professionals (d'Anjou, 2011).

\section{Methodology}

The present study employed a self-administered online questionnaire, using the Qualtrics platform. This was used to deliver a psychometric test in which respondents report their own tacit perceptions; as has been widely used for assessments of professional identity in the literature (Crossley and Vivekananda- 
Schmidt, 2009; Cowin et al., 2013). The quantitative part of the data is examined at Kunrath et al. (2017). In this sense, this study examines specifically the students' self-perception of design skills in comparison to expectations of an 'ideal designer'.

The design skills considered in this study were drawn from the recent systematic literature review by Kunrath et al. (2016). Here, Kunrath et al. describe the cognitive, technical, and behavioral skills related to the practice of design activity. This study made use of those characteristics claimed to be possible to explicitly train within the educational and practical contexts (Horváth, 2006). The survey collected information from students at two points in a design education at a technical university: bachelor $(\mathrm{N}=104)$ and master $(\mathrm{N}=79)$. Participating students where accessed during the second semester of 2016. The survey presented a response rate of $83 \%$ for bachelors and $63 \%$ for masters.

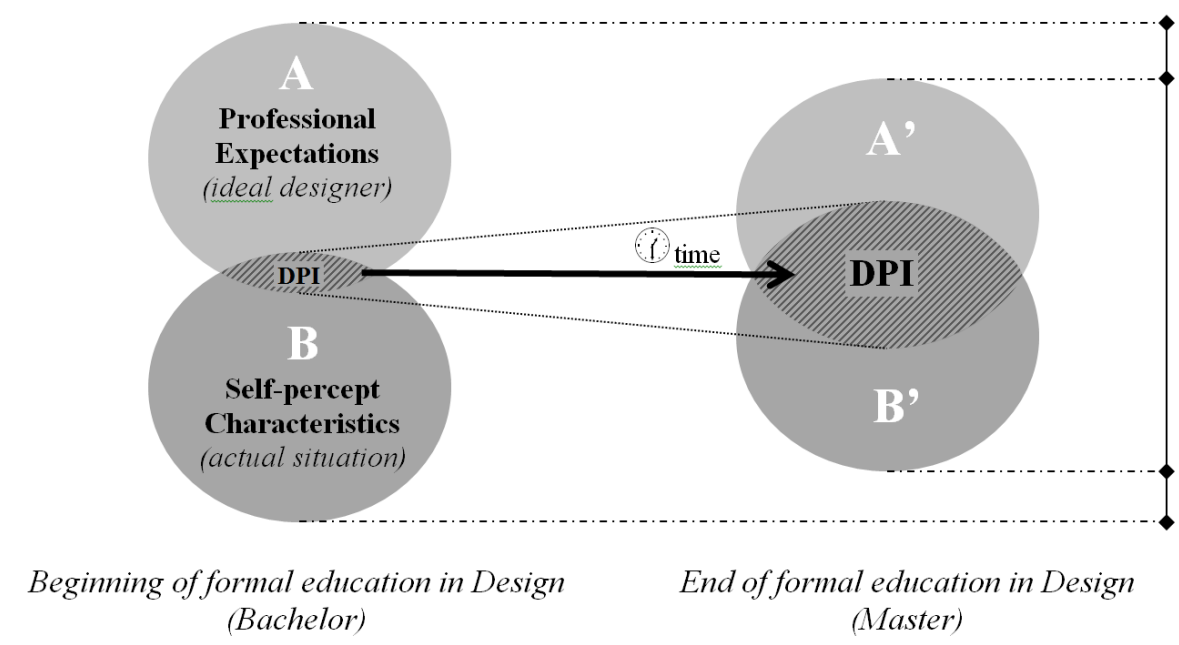

Figure 1. Framework of DPI development through the alignment between selfperception and expectation

\subsection{Survey design}

The survey was designed to allow each respondent to say how much they identify with pre-set selfstatements related to elements of design skills, in order to elicit personal constructs about skills and career development. Each element was assessed via Likert-type scale ranging from 1 (strongly disagree) to 4 (strongly agree) with a neutral option "I don't know" in the far right position of the scale. Each element comprised 6 individual items in order to increase robustness and reliability. The level of agreement with the item in question represents the level of awareness about the measured topic and alignment with the construct. The design skill elements primarily referred to the job itself, reflecting perception about behavior and performance in the workplace (see full list in Table 1).

As part of survey development, particular attention was paid to question wording so as to match prior design literature. Thus, survey design was followed four main principles: (1) reflect the construct definition derived from the design literature; (2) be distinct from the other identified characteristics; (3) not exceed a maximum length of 20 words; (4) not have an explicit measurement meaning. Table 2 illustrates, as an example, the items used for one of the measured elements. In addition to the selfperception questions participants were also asked to rank, in order of importance, the elements of design skills. The result of this ranking exercise was interpreted as expectation.

The questionnaire was comprised of a balance of positive and negative sentences (referring to the opposite relation/meaning of the intent measurement). Six items were used to assess each element to achieve adequate internal consistency and reliability yet maintain a reasonable survey length (Morgeson and Humphrey, 2006). The items were automatically randomized for each participant. Further, all the scales were refined via two waves of formal pre-tests in order to clarify the items and check readability, intelligibility, and content validity. Changes in perception across the education were analyzed relating to the two groups. 
Table 1. Designers' Professional Identity elements for design skills

\begin{tabular}{|c|c|c|c|}
\hline Categories & Elements & Description & Nr. \\
\hline \multirow[t]{2}{*}{$\begin{array}{l}\text { Cognitive } \\
\text { Skills }\end{array}$} & Cognitive Abilities & $\begin{array}{l}\text { Capacity of think 'designerly'; understanding the nature of } \\
\text { the problem to be solved; developing a distinct way of } \\
\text { thinking about the problem and solution spaces; } \\
\text { demonstrating high level of abstraction for idea generation } \\
\text { and evaluation rounds. }\end{array}$ & 6 \\
\hline & $\begin{array}{l}\text { Cognitive } \\
\text { Strategies }\end{array}$ & $\begin{array}{l}\text { Ability to set strategies of learning, problem framing, } \\
\text { solution development, and problem solving that allow the } \\
\text { flow of the cognitive abilities. }\end{array}$ & 6 \\
\hline \multirow{2}{*}{$\begin{array}{l}\text { Communication } \\
\text { Skills }\end{array}$} & $\begin{array}{l}\text { Personal } \\
\text { Communication }\end{array}$ & $\begin{array}{l}\text { Capacity to communicate clear and directly, attending to } \\
\text { details and empathising with audience. }\end{array}$ & 6 \\
\hline & $\begin{array}{l}\text { Interpersonal } \\
\text { Communication }\end{array}$ & $\begin{array}{l}\text { Awareness of communication ability in order to make } \\
\text { public presentations, set collaborations, establishing } \\
\text { rapport, and communicate among a team. }\end{array}$ & 6 \\
\hline \multirow[b]{2}{*}{$\begin{array}{l}\text { Technical } \\
\text { Skills }\end{array}$} & $\begin{array}{l}\text { Education-based } \\
\text { Knowledge }\end{array}$ & $\begin{array}{l}\text { Awareness of basic and specialized knowledge in design } \\
\text { that compounds the formal education, and domain of } \\
\text { technical and design language. }\end{array}$ & 6 \\
\hline & $\begin{array}{l}\text { Practice-based } \\
\text { Knowledge }\end{array}$ & $\begin{array}{l}\text { Abilities based and developed through practice, expertise } \\
\text { and know-how gain. Such as good } \\
\text { imagination/representation, IT competencies and use of } \\
\text { software, negotiation capacity, and appliance of previous } \\
\text { knowledge. }\end{array}$ & 6 \\
\hline \multirow{3}{*}{ Management Skills } & $\begin{array}{l}\text { Manager } \\
\text { Capacities }\end{array}$ & $\begin{array}{l}\text { Perceived competence for managing generic tasks, in a } \\
\text { personal level and with the colleagues or among the team. }\end{array}$ & 6 \\
\hline & $\begin{array}{l}\text { Project } \\
\text { Management }\end{array}$ & $\begin{array}{l}\text { Competence in developing and managing the project such } \\
\text { as planning, progressing among the tasks and phases, and } \\
\text { evaluating effectiveness and outcomes. }\end{array}$ & 6 \\
\hline & & Total number of Design Skills items in the survey & 48 \\
\hline
\end{tabular}

Table 2. Example of element's items developed and used on the survey

\begin{tabular}{llc} 
Element & Items (self-reflective sentences) & Relation \\
\hline & I find it easy to consider different perspectives on problems & + \\
\cline { 2 - 3 } Cognitive & It is easy to visualize the final product before start the design process & + \\
\cline { 2 - 3 } Abilities & Ifind it easy to simplify complex problems & + \\
\cline { 2 - 3 } & It is hard to create a new concept by associating different ideas & - \\
\cline { 2 - 3 } & It is not easy to find the key elements in a problem/solution/design. & - \\
\cline { 2 - 3 } & It is difficult to judge the intentions behind a design & - \\
\hline
\end{tabular}

\section{Results and discussion}

\subsection{Self-perception of bachelor and master students in design}

By comparing the results of the psychometric survey, as an aggregate of the four the main categories of design skills (Table 1), there is a significant trend of an increased agreement (Figure 2). The association of the reported behavior and values with the elements from literature can be consider as a reflection of the student characteristics, and indicates an increased level of awareness in each measured element. By this way, the results indicate an increase on the awareness over the period of formal education in Design, aligning with expectations from literature (Ahmed, 2007; Abdullah, 2014) and supporting the overall validity of the results from this work, providing a platform for further analysis. 


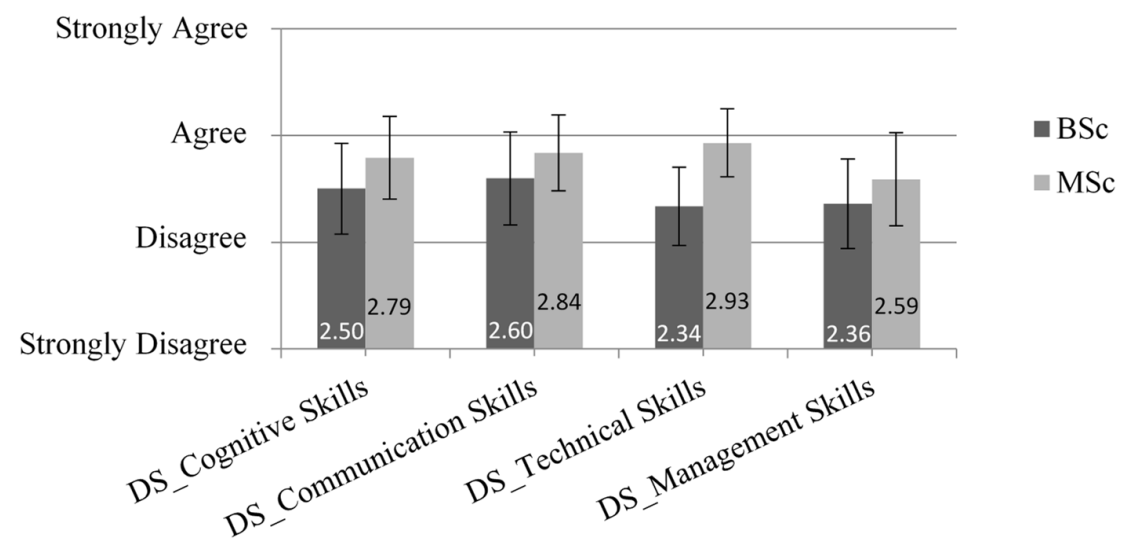

Figure 2. Graph of design skills elements from students in design

\subsection{Expectations about design skills}

When asked to rank the importance for the elements of design skills in order to describe the expected profile of an ideal designer, the surveyed students again showed substantial differences. This change in expectation was shown to be aligned with their own changing understanding of professional role associated with their on-going education. Table 3 presents the mean results of the ranked elements in order of importance based on both psychometric survey and expectation exercise.

Based on Figure 2 awareness increased across the educational. Similarly, this development of awareness reflects a change of importance attribution from Bachelor to Master students in Design (Table 3). Thus, not only does self-perception change but also the expectation of an ideal professional in Design, which challenge the development towards a socially accepted stereotype.

Table 3. Self-perception and expectation ranks of design skills for BSc and MSc (most important $=1)$

\begin{tabular}{|c|c|c|c|c|c|}
\hline & & \multicolumn{2}{|c|}{$\begin{array}{c}\text { Self-Perception } \\
\text { Rank (Scores) }\end{array}$} & \multicolumn{2}{|c|}{$\begin{array}{l}\text { Expectation Rank } \\
\text { (the ideal designer) }\end{array}$} \\
\hline & & $\mathrm{BSc}$ & $\mathrm{MSc}$ & $\mathrm{BSc}$ & MSc \\
\hline \multirow{2}{*}{ DS_Cognitive Skills } & Cognitive Abilities & 2 & 2 & 2 & 1 \\
\hline & Cognitive Strategies & 3 & 6 & 4 & 2 \\
\hline \multirow{2}{*}{ DS_Communication Skills } & Interpersonal Communication & 5 & 1 & 1 & 3 \\
\hline & Personal Communication & 1 & 8 & 8 & 6 \\
\hline \multirow{2}{*}{ DS_Technical Skills } & Education-based Knowledge & 8 & 4 & 6 & 4 \\
\hline & Practice-based Knowledge & 5 & 5 & 5 & 7 \\
\hline \multirow{2}{*}{ DS_Management Skills } & Manager Competencies & 4 & 7 & 7 & 8 \\
\hline & Project Management & 6 & 3 & 3 & 5 \\
\hline
\end{tabular}

Figure 3 elucidates the change of importance attribution from BSc to MSc students, and so the expectation for the elements of design skills. Here, some of the elements with higher value at the bachelor level, such as Interpersonal Communication, Practice-based Knowledge, and Managerial Competencies, face devaluation in order of importance at the master level. However, competencies related to the cognitive aspects of design, Personal Communication, and Knowledge from Education become more important. These differences in ideal composition indicate the development in role and values understanding; as well as a more practical and realistic approach less supported by assumption. Studies shown that simulated experiences can create a sense of real-world engagement and professional practice (Luehmann, 2007; Zou and Chan, 2016) if the context is set in a way to properly simulates a work environment when perceived by the students (Dannels, 2000), enabling earlier professional values 
to be introduced in the educational process for a more realistic the projection to what the beginners can become; fostering the process of Professional Identity formation through a clarified path of development.

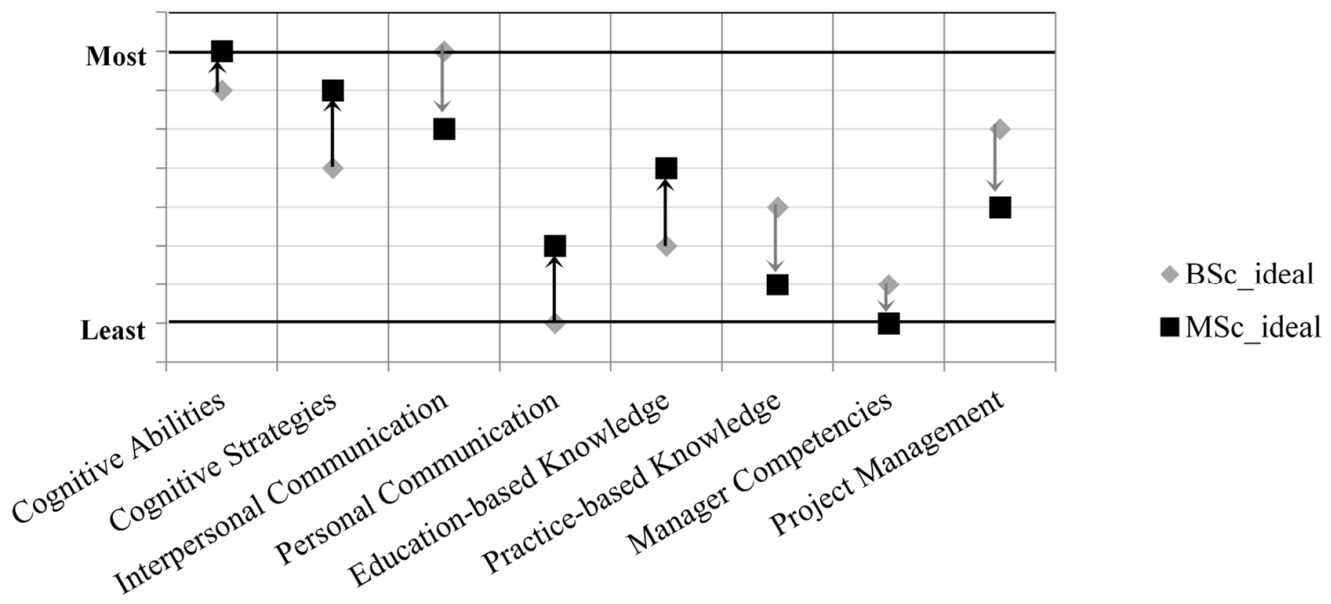

Figure 3. Differences in expectations trough the rank of design skills

\subsection{Designers' Professional Identity (DPI) development}

As highlighted in the above results evolution of self-perception and expectation reflect a shift towards the most valued characteristics identified in the design literature (Oxman, 1999; Lewis and Bonollo, 2002; Robinson et al., 2005). Figure 4 illustrates this comparison between self-perception and expectation for both bachelor and master students. The pattern on radial graphs expresses the difference in value attribution for each element of design skills. As such, the pattern visualizes the discrepancy between the results of the psychometric self-perception survey and the conceptualization of ideal composition of skills (expectation).

Bachelor students scored very low in perception of cognitive abilities, meaning that they don't recognize themselves items related to this quality. However, they attribute this element a high expected importance, just after Personal Communication. Master students, however, scored very high perception and expectation in this category, reflecting the process of awareness development. This illustrates how with knowledge and experience acquisition, students not only start to identify Cognitive Abilities as a key skills element but also start to identify themselves with the activities related to thinking, understanding, and evaluating the design problem, and so to attribute higher importance to the characteristic of 'designerly' thinking (Cross, 1999, 2001).

Similarly, Interpersonal Communication was identified, by the bachelors, as the most important skill for a designer; even though they did not identify this element in their own self-perception. The literature emphasizes the importance of external recognition for the development of professional identity since it is also socially constructed via interactions with others, particularly those within the community of practice (Dobrow and Higgins, 2005; Tracey and Hutchinson, 2013). Thus, it is possible to assume that to achieve this expectation, students invest time and effort in developing this element during their education; reflected in the high awareness and self-perception by the master students. Finally, Personal Communication is the element that most dramatically represents the change in students' mindset from bachelor to master. At bachelor level this is the skill that students identify the most, despite assigning it little expected importance. However, as knowledge from education is acquired, the importance attribution and alignment of expectation and self-perception increases at the master level. According to Tracey and Hutchinson (2013), helping novice designers to build the preliminary foundation of their professional identity is a key component of graduate training by attempting to overcome the lack of "experience, knowledge of their beliefs about design, and self-awareness of their emerging identity as 
designers" (p. 29). As such, formal training through education actively reshapes the value attribution for this and other elements of design skills (Dannels, 2000).
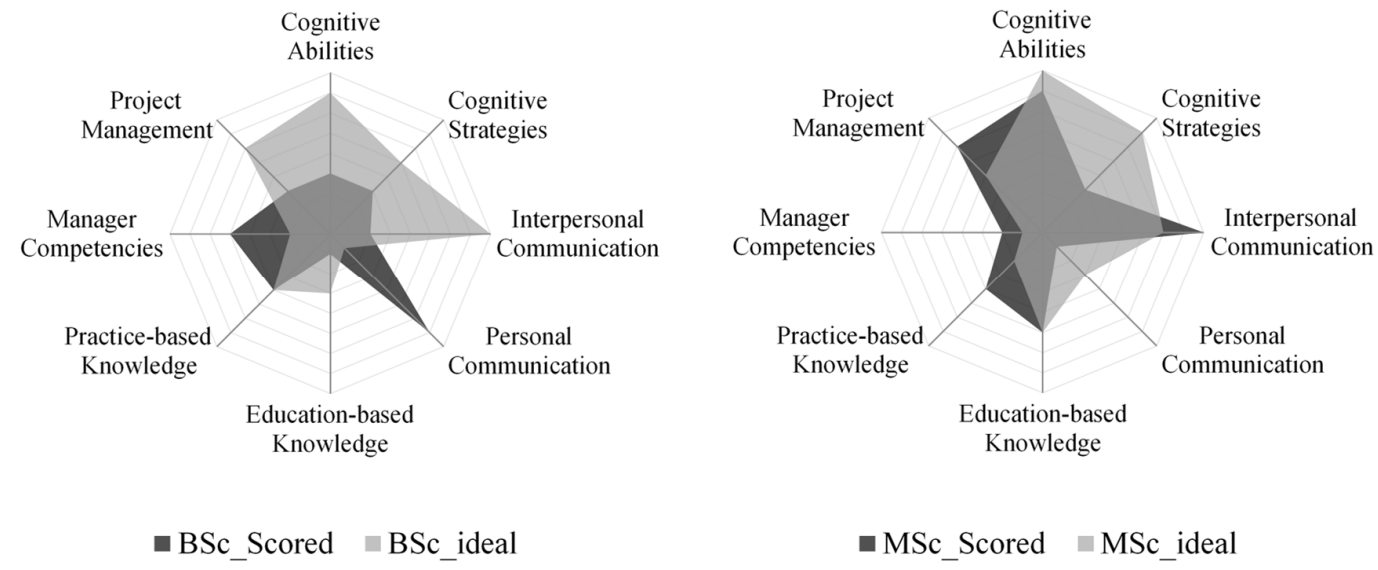

\section{Figure 4. Comparison of differences in self-perception (score means) and expectation (ranking means) on design skills for BSc and MSc}

These rearrangements of expectation and self-perception are in accordance with the research framework presented in Figure 1, and also the results illustrated in Figure 4. The differences in professional expectation and the understanding of the self also indicate the level of awareness in relation to the students' own competencies and their role as future designers. The misalignment between expectation and self-perception of Practice-based Knowledge at master lever reinforces this increase in awareness and role understanding by assuming a higher self-perception.

Research in several fields supports the idea of professional identity as a critical and formative process that occurs during an educational program and continues throughout a lifetime of practice (Skorikov and Vondracek, 2011). Although, social, demographic, and personality factors are also known to contribute and impact identity (Dobrow and Higgins, 2005; Crossley and Vivekananda-Schmidt, 2009), this study illustrates the core role of the Designers Professional Identity and its development as a complementary perspective to traditional skills focused training in design education (Mann et al., 2009; Kunrath et al., 2017). The results illustrate the changing connection between self-perceived skills and expected designerly ideal over the course of an education. The acquisition of knowledge and training during education unfold a progression in awareness, explained by the increase in self-recognition within the elements from literature, and the raise of professional belongingness and role understandings, expressed on the move towards an alignment with expectations. Thus, this extends prior conceptualizations of a relatively linear development towards the professional designer (i.e. Yang et al., 2005; Carmel-Gilfilen and Portillo, 2010). In particular, the findings reported here suggest the need for an increased focus on expectation shaping early in design education in order to mitigate the substantial disconnects between bachelor and masters expectations. This adds to prior studies that address the process to become a professional designer (Dannels, 2000; Dall'Alba, 2009; Wells et al., 2009; Adams et al., 2011), and extends theory by approaching self-perception and expectations as elements that reflect awareness and contribute to this path.

\section{Implications and limitations}

Key implications of this research are the need to better understand the scope of self-perception and identity development in designers over time - including during professional development. Further, this work highlights the importance of addressing both practical skills and expectation early in design education in order to better align professional development and self-realization.

Further work should address the inclusion of design professionals in order to provide a deep understanding of the reflections of self-perception and expectation development towards DPI. An in- 
depth qualitative study could also enrich this area by pointing out nuances and interpretations, revealing the understanding of the participants about design roles and values in a contextualized approach. However, this work contributes to understanding of how designers develop during the educational process in a technical university and points to the need for further work specifically in resolving what constitutes designers professional identity, and how this develops over time in a deeper and broader sense.

\section{Conclusions}

This work set out to start to answer the RQs: 1) How does students' expectation, of the ideal skills composition for a designer, evolve over the course of education? 2) What are the differences between the students' self-perception and expectation? By understanding this interaction between self-perception and professional expectation is an important aspect in professional development and professional identity. Further, it also allows the designer to set goals in order to focus training and efforts towards a projection of a 'strongly qualified' professional.

Based on the reported results is possible to conclude that, more than the expected alignment suggested by prior literature, students were able to direct their training towards their expectations. Thus, setting the projection of the ideal professional as a goal to be achieved, students unfold both self-awareness and professional expectation. However, this reflective process was not a linear development, with a number of skills rising and falling in importance with respect to both self-perception and expectation; bringing new challenges based on the strengthening, reinforcement, and usage of a designerly mindset. Thus, this research highlights the need for an earlier and better understanding of the composition of and alignment between professional identity development and education/career path. In particular, this has significant implications for design education, professional development, and theory regarding design mindset and identity.

\section{Acknowledgment}

The authors are grateful to the National Council for Scientific and Technological Development (CNPq)/Brazil that has sponsored the first author via Ph.D. scholarship (201719/2014-2).

\section{References}

Abdullah, Z. (2014), “Activity Theory as Analytical Tool: A Case Study of Developing Student Teachers' Creativity in Design", Procedia - Social and Behavioral Sciences, Vol. 131 No. 15, pp. 70-84. https://doi.org/10.1016/j.sbspro.2014.04.082

Adams, R.S., Daly, S.R., Mann, L.M. and Dall'Alba, G. (2011), "Being a professional: Three lenses into design thinking, acting, and being”, Design Studies, Vol. 32 No. 6, pp. 588-607. https://doi.org//10.1016/j.destud.2011.07.004

Ahmed, S. (2007), “An Industrial Case Study: Identification of Competencies of Design Engineers”, Journal of Mechanical Design, Vol. 129 No. 7, pp. 709-716. https://doi.org/10.1115/1.2723807

Ashcraft, K.L. (2013), “The Glass Slipper: 'Incorporating' Occupational Identity in Management Studies”, Academy of Management Review, Vol. 38 No. 1, pp. 6-31. https://doi.org/10.5465/amr.2010.0219

Carmel-Gilfilen, C. and Portillo, M. (2010), "Developmental trajectories in design thinking: an examination of criteria”, Design Studies, Vol. 31 No. 1, pp. 74-91. https://doi.org/10.1016/j.destud.2009.06.004

Cowin, L.S., Johnson, M., Wilson, I. and Borgese, K. (2013), "The psychometric properties of five Professional Identity measures in a sample of nursing students", Nurse Education Today, Vol. 33 No. 6, pp. 608-613. https://doi.org/10.1016/j.nedt.2012.07.008

Cross, N. (1982), "Designerly ways of knowing”, Design Studies, Vol. 3 No. 4, pp. $221-227$. https://doi.org/10.1016/0142-694X(82)90040-0

Cross, N. (1999), "Natural intelligence in design", Design Studies, Vol. 20 No. 1, pp. 25-39. https://doi.org/10.1016/S0142-694X(98)00026-X

Cross, N. (2001), "Designerly Ways of Knowing: Design Discipline Versus Design Science”, Design Issues, Vol. 17 No. 3, pp. 49-55. https://doi.org/10.1162/074793601750357196 
Crossley, J. and Vivekananda-Schmidt, P. (2009), "The development and evaluation of a Professional Self Identity Questionnaire to measure evolving professional self-identity in health and social care students", Medical Teacher, Vol. 31 No. 12, pp. e603-e607. https://doi.org/10.3109/01421590903193547

d'Anjou, P. (2011), "An alternative model for ethical decision-making in design: A Sartrean approach", Design Studies, Vol. 32 No. 1, pp. 45-59. https://doi.org/10.1016/j.destud.2010.06.003

Dall'Alba, G. (2009), "Learning professional ways of being: Ambiguities of becoming”, Educational Philosophy and Theory, Vol. 41 No. 1, pp. 34-45. https://doi.org/10.1111/j.1469-5812.2008.00475.x

Dannels, D.P. (2000), "Learning to Be Professional”, Journal of Business and Technical Communication, Vol. 14 No. 1, pp. 5-37. https://doi.org/10.1177/105065190001400101

Dobrow, S.R. and Higgins, M.C. (2005), "Developmental networks and professional identity: a longitudinal study", Career Development International, Vol. 10 No. 6/7, pp. 567-583. https://doi.org/10.1108/13620430510620629

Evetts, J. (2003), “The Sociological Analysis of Professionalism”, International Sociology, Vol. 18 No. 2, pp. 395-415. https://doi.org/10.1177/0268580903018002005

Freiberger, V., Steinmayr, R. and Spinath, B. (2012), "Competence beliefs and perceived ability evaluations : How do they contribute to intrinsic motivation and achievement?", Learning and Individual Differences, Vol. 22 No. 4, pp. 518-522. https://doi.org/10.1016/j.lindif.2012.02.004

Gorges, J. and Kandler, C. (2012), “Adults' learning motivation: Expectancy of success, value, and the role of affective memories", Learning and Individual Differences, Vol. 22 No. 5, pp. 610-617. https://doi.org/10.1016/j.lindif.2011.09.016

Horváth, I. (2006), "Design Competence Development in an Academic Virtual Enterprise", Volume 3: 26th Computers and Information in Engineering Conference, Philadelphia, USA, September 10-13, 2006, ASME, pp. 383-392. https://doi.org/10.1115/DETC2006-99162

Kunrath, K., Cash, P.J. and Li-Ying, J. (2016), "Designer's Identity: Personal Attributes and Design Skills", Proceedings of DESIGN 2016 / the 14 $4^{\text {th }}$ International Design Conference, Dubrovnik, Croatia, May 16-19, 2016, The Design Society, pp. 1729-1740.

Kunrath, K., Cash, P.J. and Li-Ying, J. (2017), "Designer's Identity: Development of Personal Attributes and Design Skills over Education", Proceedings of the $21^{\text {st }}$ International Conference on Engineering Design, Vancouver, Canada, August 21-25, 2017, The Design Society, pp. 419-428.

Lewis, W.P. and Bonollo, E. (2002), “An analysis of professional skills in design: implications for education and research”, Design Studies, Vol. 23 No. 4, pp. 385-406. https://doi.org/10.1016/S0142-694X(02)00003-0

Luehmann, A.L. (2007), "Identity development as a lens to science teacher preparation", Science Education, Vol. 91 No. 5, pp. 822-839. https://doi.org/10.1002/sce.20209

Mann, L., Howard, P., Nouwens, F. and Martin, F. (2009), "Influences on the Development of Students' Professional Identity as an Engineer", Proceedings of the Research in Engineering Education Symposium, Palm Cove, QLD, pp. 1-6.

Morgeson, F.P. and Humphrey, S.E. (2006), “The Work Design Questionnaire ( WDQ ): Developing and Validating a Comprehensive Measure for Assessing Job Design and the Nature of Work", Journal of Applied Psychology, Vol. 91 No. 6, pp. 1321-1339. https://doi.org/10.1037/0021-9010.91.6.1321

Oxman, R. (1999), "Educating the designerly thinker", Design Studies, Vol. 20 No. 2, pp. $105-122$. https://doi.org/10.1016/S0142-694X(98)00029-5

Robinson, M.A., Sparrow, P.R., Clegg, C. and Birdi, K. (2005), "Design engineering competencies: future requirements and predicted changes in the forthcoming decade”, Design Studies, Vol. 26 No. 2, pp. $123-153$. https://doi.org/10.1016/j.destud.2004.09.004

Schwartz, S.J., Luyckx, K. and Vignoles, V.L. (2011), Handbook of Identity Theory and Research, Springer, New York. https://doi.org/10.1007/978-1-4419-7988-9

Tracey, M.W. and Hutchinson, A. (2013), “Developing Designer Identity Through Reflection”, Educational Technology, Vol. 53 No. 3, pp. 28-32.

Wells, P., Gerbic, P., Kranenburg, I. and Bygrave, J. (2009), "Professional Skills and Capabilities of Accounting Graduates: The New Zealand Expectation Gap?”, Accounting Education, Vol. 18 No. 4-5, pp. 403-420. https://doi.org/10.1080/09639280902719390 
Wigfield, A. and Eccles, J.S. (2000), "Expectancy-Value Theory of Achievement Motivation", Contemporary Educational Psychology, Vol. 25 No. 1, pp. 68-81. https://doi.org/10.1006/ceps.1999.1015

Yang, M.-Y., You, M. and Chen, F.-C. (2005), "Competencies and qualifications for industrial design jobs: implications for design practice, education, and student career guidance”, Design Studies, Vol. 26 No. 2, pp. 155-189. https://doi.org/10.1016/j.destud.2004.09.003

Zou, T.X. and Chan, B.Y. (2016), "Developing professional identity through authentic learning experiences", Research and Development in Higher Education: The Shape of Higher Education, Vol. 39. Fremantle, Australia, July 4-7, 2016, Higher Education Research and Development Society of Australasia Inc., pp. 383391.

Kamila Kunrath, PhD Student

Technical University of Denmark, Department of Management Engineering

Diplomvej, 372 - Room 231, 2800 Kgs. Lyngby, Denmark

Email:kaku@dtu.dk 